\title{
Penguatan Peran Pesantren untuk Membangun Pertahanan Umat Islam Indonesia di Era Society 5.0
}

\author{
(Strengthening the Role of Islamic Boarding School to Build \\ the Defense of Indonesian Muslims \\ in the Era of Society 5.0)
}

\author{
Marzuki $^{*}$, Budi Santoso² ${ }^{2}$ Muhammad Abdul Ghofur ${ }^{3}$ \\ ${ }^{1}$ Fakultas Ilmu Sosial, Universitas Negeri Yogyakarta, Yogyakarta, Indonesia \\ ${ }^{2}$ Departemen Teknik Manajemen Industri, Akademi Angkatan Udara, Yogyakarta, Indonesia \\ ${ }^{3}$ Departemen Aeronautika, Akademi Angkatan Udara, Yogyakarta, Indonesia \\ E-mail:marzuki@uny.ac.id,budi.bodjong@gmail.com,m_abdulghofur@aau.ac.id
}

\begin{abstract}
This study aims to analyze the strengthening of the role of Islamic boarding schools (pesantren) to build the defense of Indonesian Muslims in the era of society 5.0. Pesantren which is one of the oldest Islamic educational institutions in Indonesia has several main characteristics such as the existence of cottages, mosques, santri (student), ustaz (teacher), kiai, and the yellow book learning. This research is a qualitative research in the form of library research with content analysis method. Sources of data are in the form of several manuscripts, both books and scientific journal articles containing relevant studies to various efforts to strengthen the role of pesantren in strengthening Indonesian Muslims in the era of society 5.0. Data analysis was carried out interactively. The results of the study indicate that pesantren is Islamic educational institutions that has quite a lot of goals, roles, and functions in the midst of society in line with the goals, roles, and functions of Islamic education. Pesantren is also an Islamic educational institution that plays an important role in strengthening Indonesian Muslims so that they have defense and resilience in facing various changes and dynamics of life in the era of society 5.0. Important aspects built by pesantren for the defense and resilience of Muslims include religious, character, educational, social, and economic aspects. As a leading Islamic educational institution in Indonesia, pesantren must be able to equip every Muslim in the current era of society 5.0 so that they can maintain their identity as Indonesian people who uphold religious values and human values.
\end{abstract}

Keywords - The role of pesantren, the Muslims defense, Indonesia, Society 5.0

Abstrak- Penelitian ini bertujuan untuk menganalisis penguatan peran pesantren untuk membangun daya tahan umat Islam Indonesia di era society 5.0. Pesantren yang merupakan salah satu lembaga pendidikan Islam tertua di Indonesia memiliki beberapa ciri pokok seperti adanya pondok, masjid, santri, ustaz, kiai, dan pembelajaran kitab kuning. Penelitian ini merupakan penelitian kualitatif dengan bentuk penelitian kepustakaan (library research) dengan metode analisisi isi (content analysis). Sumber data berupa beberapa manuskrip baik buku maupun artikel jurnal ilmiah yang berisi kajian-kajian yang relevan dengan berbagai upaya penguatan peran pesantren dalam pemberdayaan umat Islam Indonesia di era society 5.0. Analisis data dilakukan secara interaktif. Hasil penelitian menunjukkan bahwa pesantren merupakan lembaga pendidikan Islam yang memiliki tujuan, peran, dan fungsi yang cukup banyak di tengah-tengah masyarakat seiring dan sejalan dengan tujuan, peran, dan fungsi pendidikan Islam. Pesantren juga merupakan lembaga

*Penulis Korespondensi (Marzuki)

E-mail:marzuki@uny.ac.id 
pendidikan Islam yang berperan penting dalam pemberdayaan umat Islam Indonesia sehingga memiliki ketahanan dalam menghadapi berbagai perubahan dan dinamika kehidupan di era society 5.0. Aspek penting yang dibangun pesantren untuk pertahanan dan ketahanan umat Islam di antaranya aspek keagamaan, karakter, pendidikan, sosial, dan ekonomi. Sebagai institusi pendidikan Islam terkemuka di Indonesia pesantren harus mampu membekali setiap Muslim di era society 5.0 sekarang ini agar tetap dapat mempertahankan jati dirinya sebagai manusia Indonesia yang menjunjung tinggi nilai-nilai religius dan nilai-nilai kemanusiaan.

Kata Kunci—Peran pesantren, ketahanan umat Islam, Indonesia, Society 5.0.

\section{PENDAHULUAN}

Tndonesia merupakan salah satu negara yang berpenduduk terbesar di dunia. Indonesia juga

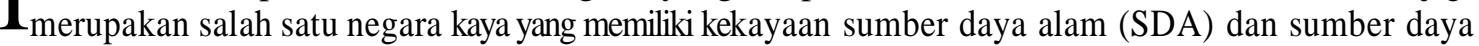
manusia (SDM) yang melimpah. Indonesia memiliki ribuan pulau yang terbentang dari Pulau We di Provinsi Aceh sampai Pulau Rote di Provinsi Papua dengan berbagai kandungan alamnya.Ada 17.504 pulau di Indonesia yang tersebar di 34 provinsi. Di samping itu, Indonesia memiliki lebih dari 400 gunung berapi, lebih dari 18\% terumbu karang dunia, dan kekayaan alam lainnya [1], [2].

Meskipun umat Islam Indonesia tidak termasuk generasi umat awal yang memeluk Islam, akan tetapi sekarang ini (tahun 2020), umat Islam Indonesia menjadi umat Islam terbesar di antara umat-umat Islam yang ada di dunia. Berdasarkan data proyeksi Global Religious Futures, penduduk Indonesia yang beragama Islam berjumlah 229,62 juta jiwa. Angka tersebut sebesar $10,51 \%$ dari total penduduk muslim dunia [3]. Sebagai negara mayoritas muslim dunia, keberadaan Indonesia dengan keaneka-ragaman ras, suku, dan budayanya, tentunya mempengaruhi perkembangan dan penyelenggaan pendidikannya. Pesantren merupakan salah satu sistem pendidikan Islam khas di Indonesia selain sistem pendidikan Islam lainnya, dari tingkat dasar hingga perguruan tinggi, baik negeri maupun swasta.

Permasalahan pendidikan Islam di Indonesia menjadi sangat penting untuk diperhatikan dalam rangka menjaga agar agama Islam dengan seluruh ajarannya tetap terjaga dan terus terwariskan dari generasi ke generasi dengan baik dan benar. Keanekaragaman suku, ras, budaya, dan adat istiadat di Indonesia tentu memberikan pengaruh yang signifikan terhadap perkembangan dan dinamika Pendidikan di Indonesia [4]. Untuk itulah institusi pendidikan di Indonesia menjadi suatu yang sangat dibutuhkan untuk memfasilitasi pewarisan keilmuwan Islam dengan segala pengamalan ajaran Islam di tengah keberagaman suku, ras, dan budaya tersebut. Institusi tertua yang dibangun untuk fungsi ini yaitu pesantren atau pondok pesantren dengan berbagai bentuk dan variasinya. Pada masa penjajahan, pesantren memiliki peran utama sebagai pusat pendidikan Islam di Indonesia di samping peran dan fungsi lainnya [5], [6], [7].

Secara umum pesantren menjadi pusat pendidikan Islam yang telah mampu mewariskan tradisi keislaman yang terpercaya dari generasi ke generasi. Bahkan pesantren diakui sebagai salah satu institusi yang dapat mendorong terwujudnya multikulturalisme di kalangan umat Islam yang menjunjung tinggi nilai toleransi dan keberagaman [8]. Seiring perkembangan zaman pesantren juga mengalami perkembangan dalam peran dan fungsinya. Perkembangan peran pesantren tidak dapat dilepaskan dari pengasuh, kiai, dan ustaznya. Materi ajar yang diberikan untuk para santri juga sangat tergantung kepada para pengasuhnya, mengingat tidak adanya kurikulum tertentu yang harus diikuti. Akibatnya, pesantren kemudian menjadi tempat penyebaran paham-paham yang tidak mainstream keislaman, seperti paham radikal yang intoleran terhadap kelompok-kelompok tertentu [9], [10], [11].

Seiring perkembangan zaman yang melaju sangat cepat, pendidikan Islam harus mampu mengikutinya dengan baik. Pendidikan pesantren dengan demikian juga harus berupaya 
mengikuti perkembangan yang terjadi di tengah-tengah masyarakat Indonesia, termasuk perkembangan di dunia internasional. Dunia sekarang sudah memasuki era baru yang disebut era industri 4.0 atau juga disebut revolusi industri 4.0. Dalam waktu dekat diperkirakan dunia akan memasuki era society 5.0 atau era masyarakat 5.0. Revolusi industri 4.0 yang ditandai dengan perkembangan IPTEKS harus menjadi perhatian pendidikan nasional, khususnya pendidikan Islam, termasuk pendidikan pesantren. Setiap guru, ustaz, pengasuh, dan kiai di pesantren harus melakukan pendidikan dan pembelajaran yang seiring dan sejalan dengan tuntutan era industri 4.0 tersebut sehingga para santri (peserta didik) yang mengikuti pendidikan dan pembelajaran akan menjadi manusia-manusia muslim Indonesia yang memiliki pemahaman Islam yang benar dan memiliki wawasan yang luas dan terbuka seiring dengan perkembangan dunia yang ada.

Era society 5.0 ditandai dengan berkembangnya sistem E-commerce dan digitalisasi industri di tengah masyarakat. Era baru ini digagas dan dimunculkan oleh pemerintah Jepang sebagai kelanjutan dari era sebelumnya, yakni revolusi industri 4.0 [12]. Society 5.0 dinyatakan sebagai rencana besar berupa transformasi digital dan automatisasi yang diluncurkan oleh pemerintah Jepang yang dianggap super ambisius sehingga memunculkan pertanyaan di benak banyak orang, mengapa harus era society 5.0? padahal semua negara masih mendiskusikan era industri 4.0. Penamaan era industri 4.0 berawal dari Jerman pada tahun 2011 sedangkan negara lain yang ikut mewujudkan konsep era industri 4.0 memberikan nama lain seperti Smart Factories, Industrial Internet of Things, Smart Industry, atau Advanced Manufacturing [13].

Masyarakat 5.0 merupakan konsep masyarakat yang berpusat pada manusia (human centered) dan berbasis teknologi (technology based). Masyarakat 5.0 juga sebagai sebuah konsep dalam masyarakat yang berfokus pada manusia berbasis teknologi [14]. Konsep ini lahir sebagai pengembangan dari revolusi industri 4.0 yang dinilai berpotensi yang mendegradasi peran manusia. Di era masyarakat 5.0 bukan lagi modal yang paling penting, akan tetapi data yang dapat menghubungkan dan menggerakkan segalanya serta membantu mengisi kesenjangan antara yang kaya dan kurang kaya. Masyarakat 5.0 merupakan masyarakat yang menerapkan teknologi yang berfokus pada kehidupan manusia berlandaskan pada kebiasaan di era industri 4.0. [15].

Perkembangan IPTEKS di era industri 4.0 yang diikuti dengan begitu kuatnya peran masyarakat yang menguasai teknologi di era society 5.0 memiliki pengaruh yang sangat signifikan terhadap dinamika di tengah masyarakat dunia, termasuk di Indonesia, dalam semua aspek kehidupan mereka. Lembaga pendidikan menjadi institusi yang paling terpengaruh oleh perkembangan era industri 4.0 dan era society 5.0. Salah satu institusi pendidikan Islam yang harus berperan dalam menyongsong perkembangan dunia ini dan untuk membangun daya tahan para peserta didik khususnya dan umat Islam umumnya agar tetap eksis dengan jati dirinya sebagai Muslim yaitu pesantren. Penelitian ini berusaha untuk mengkaji dan menganalisis bagaimana menguatkan peran pesantren guna membangun daya tahan umat Islam seiring dengan perkembangan yang terjadi di era society 5.0.

\section{LANDASAN TEORI}

\section{A. Kajian tentang Pendidikan Islam}

Pendidikan Islam adalah sistem pendidikan yang Islami yang teori-teorinya disusun berdasarkan Alquran dan hadis. Di Indonesia dikenal juga istilah Pendidikan Agama Islam yang dibakukan sebagai nama mata pelajaran (mata kuliah) dan juga kegiatan dalam mendidikkan agama Islam. Pendidikan Agama Islam dipahami sebagai usaha-usaha dalam mendidikkan agama Islam [16]. Istilah Pendidikan Islam memiliki cakupan yang luas (umum) yang disejajarkan dengan pendidikan-pendidikan umum lainnya, seperti Pendidikan Pancasila, Pendidikan Kewarganegaraan, 
Pendidikan Nilai, Pendidikan Karakter, dan Pendidikan Olahraga yang bisa saja menjadi nama mata pelajaran khusus atau terintegrasi dalam pembelajaran berbagai mata pelajaran dalam kurikulum tertentu. Sedangkan istilah Pendidikan Agama Islam lebih spesifik cakupannya.

Inti dari pendidikan Islam adalah pendidikan akhlak atau pendidikan budi pekerti [17]. Sebagai bagian dari pendidikan nasional, pendidikan Islam yang menjadi turunan dari Pendidikan Agama mempunyai peran yang sangat penting dan strategis dalam rangka mewujudkan fungsi dan tujuan pendidikan nasional. Pada Pasal 2 ayat (1) Peraturan Pemerintah RI Nomor 55 Tahun 2007 tentang Pendidikan Agama dan Pendidikan Keagamaan secara tegas dinyatakan bahwa Pendidikan Agama berfungsi membentuk manusia Indonesia yang beriman dan bertakwa kepada Tuhan Yang Maha Esa serta berakhlak mulia dan mampu menjaga kedamaian dan kerukunan hubungan inter dan antarumat beragama.

Materi pokok pendidikan Islam yaitu ajaran Islam yang bertumpu pada tiga kerangka dasar Islam, yakni akidah (keimanan), syariah (aturan-aturan hukum tentang ibadah dan muamalah), dan akhlak (karakter). Ketiga bagian ajaran Islam ini tidak bisa dipisahkan dan merupakan satu kesatuan utuh yang saling terkait dan memengaruhi. Akidah merupakan fondasi yang menjadi tumpuan untuk terwujudnya syariah dan akhlak. Sementara itu, syariah merupakan bentuk bangunan yang akan bisa terwujud dan berdiri kokoh bila dilandasi oleh akidah yang benar dan akan mengarah pada pencapaian akhlak (karakter) yang seutuhnya. Tujuan pendidikan Islam yaitu membina manusia agar mampu memahami, menghayati, meyakini, dan mengamalkan ajaran Islam dalam kehidupannya sehingga menjadi insan kamil, yaitu manusia yang beriman, bertakwa kepada Allah Swt., dan berkarakter mulia [18]. Seorang muslim yang memiliki pemahaman yang benar akan ajaran Islamnya diharapkan akan menjadi manusia tangguh yang mampu bertahan dengan jati diri keislamannya di tengah perkembangan dan perubahan yang terjadi di sekelilingnya.

\section{B. Konsep Pesantren}

Pesantren merupakan salah satu lembaga pendidikan Islam di Indonesia. Pesantren dikenal di tengah masyarakat dengan istilah pondok pesantren. Pesantren juga merupakan lembaga pendidikan pertama dan tertua di Indonesia. Selain itu, pesantren merupakan bentuk pendidikan tradisional di Indonesia yang sejarahnya telah mengakar secara berabadabad jauh sebelum Indonesia merdeka dan sebelum kerajaan Islam berdiri, sehingga ada yang menyebutkan bahwa pesantren mengandung makna keislaman sekaligus keaslian (indigenous) Indonesia [19].

Kata pesantren secara terminologi diambil dari kata "santri" mendapat awalan "pe" dan akhiran "an" yang artinya tempat, tempat menuntut ilmu para santri. Kata "santri" juga bisa berarti manusia baik dan suka menolong. Pesantren dapat didefinisikan sebagai tempat belajar bagi orang baik-baik [20]. Kata "pesantren" mengandung pengertian sebagai tempat para santri atau murid pesantren, sedangkan kata "santri" menurut sebagian ahli berasal dari bahasa Tamil atau bahasa Sansekerta, yakni "sastri" yang berarti guru ngaji, melek huruf, atau dari bahasa Jawa, "cantrik" yang berarti orang yang mengikuti gurunya ke mana pun pergi. Dari sini dapat dipahami bahwa pesantren setidaknya memiliki tiga unsur, yakni santri, kiai, dan asrama. Pesantren pada dasarnya merupakan sebuah asrama pendidikan Islam tradisional yang para santrinya tinggal bersama dan belajar ilmu-ilmu keagamaan di bawah bimbingan guru yang lebih dikenal dengan sebutan kiai. Asrama untuk para siswa tersebut berada dalam kompleks pesantren tempat sang kiai bertempat tinggal. Pesantren dilengkapi fasilitas ibadah yang berupa masjid. Biasanya kompleks pesantren dikelilingi dengan tembok untuk memudahkan mengawasi keluar masuknya santri [21].

Di kalangan masyarakat pesantren juga populer dengan nama "pondok" yang berarti kamar, gubug, rumah kecil yang memiliki pola bangunan yang sederhana. Ada yang 
berpendapat kata pondok berasal dari bahasa Arab "funduq" yang artinya rumah, tempat tidur, hotel, rumah sederhana yang dibuat dengan bahan utamanya adalah bambu. Oleh karena itu, pesantren juga dapat berarti bangunan sederhana berbentuk asrama atau kamarkamar kecil tempat para santri belajar ilmu agama dengan kiai atau guru ngaji [22], [23]. Istilah lain yang semakna dengan pesantren yaitu al-ma'had, yang artinya kampus, area, atau lokasi pendidikan. Oleh karena itu, di pesantren para santri harus tinggal di pondok atau di area kampus yang di sini mereka makan bersama, mengaji, berzikir, berdoa, dan salat berjamaah, mengikuti pengajian secara rutin setelah salat magrib, isyak, shubuh, di tengah malam mereka tahajjud, dan selainnya [24].

Pesantren juga merupakan institusi pendidikan Islam yang asli Indonesia, sebagai rujukan dan acuan umat Islam untuk mengamalkan ajaran agama Islam dalam kehidupan umat manusia [25]. Ciri pesantren, terutama pesantren salaf, dapat dilihat dalam hal sistem pembelajaran dan materi yang diajarkan. Ciri yang menonjol dalam pesantren salaf yaitu adanya pengajaran kitab-kitab Islam klasik atau sering disebut dengan "kitab kuning", karena kertasnya berwarna kuning, terutama karangan-karangan ulama yang menganut paham Syafi'iyah. Semua ini merupakan pengajaran formal yang diberikan dalam lingkungan pesantren tradisional [26]. Ciri pokok pesantren yang lain yaitu pondok, masjid, santri, dan kiai. Semua orang yang ada di lingkungan pesantren menjadi tanggung jawab kiai atau pengasuh pesantren yang dibantu oleh para ustaz dan guru. Pendidikan di pesantren tidak hanya yang diberikan oleh kiai di masjid (musala) tetapi juga oleh para ustaz di tempat-tempat yang disediakan untuk pembelajaran baik yang formal (di kelas-kelas) maupun nonformal (di kamar-kamar) termasuk pengalaman sehari-hari di lingkungan pesantren.

\section{METODE}

Penelitian ini menggunakan pendekatan kualitatif dalam bentuk penelitian kepustakaan (library research). yakni penelitian yang dilakukan melalui pengumpulan data atau karya tulis ilmiah yang bertujuan untuk memecahkan suatu masalah. Penelitian kepustakaan mengarahkan penelitiannya pada pengkajian dan penelusuran ide-ide dan khazanah pemikiran pada sumbersumber kepustakaan seperti manuskrip atau naskah, buku, jurnal, dan karya tulis ilmiah lainnya. Jadi, untuk meneliti penguatan peran pesantren dalam rangka membangun pertahanan umat Islam di era society 5.0 digunakan sumber-sumber dari karya-karya tulis yang relevan.

Sumber data penelitian berupa beberapa buku dan jurnal ilmiah yang berisi kajian-kajian yang relevan dengan objek kajian penelitian ini. Untuk mengolah dan menganalisis semua data dari literatur serta teks, digunakan metode content analysis. Metode content analysis di dalam mengukur tingkat akurasi dan proses penarikan simpulan terhadap pesan, setidaknya memiliki tiga langkah yang dapat dilakukan, yaitu deskriptif, analisis isi secara kritis, dan korelatif [27]. Proses pengolahan data dikelompokkan kepada tiga tahapan meliputi, aktivitas pengumpulan data dari referensi-referensi yang kemudian mengelompokkannya dan mendeskripsikannya; kedua, kegiatan analisis data setelah mendeskripsikan konsep-konsep pemikiran dan ide-ide, kemudian dianalisis dengan menggunakan pisau analisis pola berpikir analitik induktif, deduktif, dan interaktif (perpaduan induktif dengan deduktif); dan ketiga memberikan penafsiran dan pemaknaan terhadap hasil analisis yang bertujuan untuk mengambil simpulan.

\section{HASIL DAN PEMBAHASAN}

\section{A. Pesantren sebagai Lembaga Pendidikan Islam}

Sebagai salah satu lembaga pendidikan Islam, pesantren memiliki tujuan, peran, dan fungsi yang cukup banyak di tengah-tengah masyarakat seiring dan sejalan dengan tujuan, peran, dan 
fungsi Pendidikan Islam. Dari berbagai sumber dan kajian tentang Pendidikan Islam, maka secara umum tujuan Pendidikan Islam yaitu: 1) mengenalkan manusia akan perannya di antara makhluk lain serta tanggung jawab pribadinya di dalam hidup ini; 2) mengenalkan manusia akan interaksi sosial dan tanggung jawabnya dalam tata hidup masyarakat; 3) mengenalkan manusia akan alam ini dan mengajarkannya untuk mengetahui hikmah diciptakannya, serta memberikan kemungkinan kepadanya untuk mengambil manfaat dari alam tersebut; 4) mengenalkan manusia akan pencipta alam ini (Allah Swt.) dan beribadah kepada-Nya [28].

Fungsi pendidikan Islam tidak saja menyiapkan tenaga terdidik untuk meraih tujuan-tujuan sementara, namun lebih dari itu, pendidikan Islam secara umum berfungsi membina manusia yang mampu membangun dunia dengan segala dimensinya, sesuai dengan komitmen imannya terhadap Allah Swt. Untuk lebih memperjelas fungsi pendidikan Islam di era global dan era milenial ini, dapat ditinjau dari fenomena yang muncul dalam perkembangan peradaban manusia, dengan asumsi bahwa peradaban manusia di era ini senantiasa tumbuh dan berkembang melalui pendidikan. Manusia di era ini diperhadapkan dengan dilema semakin berkembangnya IPTEKS dan teknologi informasi. Aneka ragam informasi dapat diterima dalam sesaat sehingga wawasan manusia semakin luas. Di sinilah pendidikan Islam harus tetap mengembangkan wawasan manusia berdasarkan ajaran Islam, yakni memberikan kemampuan membaca (iqra'/iterasi) pada peserta didik [29]. Pendidikan Islam, tidak terlepas dari lembagalembaga yang disebut juga institusi atau pranata pendidikan. Lembaga pendidikan Islam yang dimaksud di sini adalah wadah atau tempat berlangsungnya proses pendidikan Islam yang bersamaan dengan proses pembudayaan. Terkait dengan ini, pesantren memainkan peran-peran yang sangat urgen dalam pendidikan.

Masjid merupakan bagian penting dari pesantren yang memiliki banyak fungsi. Selain berfungsi sebagai tempat salat berjamaah, masjid juga berfungsi sebagai tempat belajar mengajar (pembelajaran) di pesantren. Pada sebagian pesantren masjid juga berfungsi sebagai tempat iktikaf dan melaksanakan latihan-latihan, atau suluk dan zikir, dan amalan-amalan lainnya dalam kehidupan tarekat dan sufi. Masjid di sini sebagai pusat pendidikan dalam tradisi pesantren dan merupakan manifestasi universalisme dari sistem pendidikan tradisional [30]. Dengan demikian, masjid merupakan elemen pokok yang tidak dapat dipisahkan dari pesantren dan dianggap sebagai tempat yang paling tepat untuk mendidik para santri, terutama dalam hal praktik salat lima waktu secara berjamaah, ceramah, khutbah, dan pengajaran kitab- kitab Islam klasik [31].

Dapat dipahami bahwa kedudukan pesantren dengan berbagai unsur dan elemennya yakni pondok, mesjid, pengajian kitab, santri dan kiai merupakan media dan lembaga pendidikan Islam tradisional di Indonesia, yang memiliki kedudukan signifikan dan merupakan kebutuhan zaman. Hal ini bisa dilihat dari perjalanan historinya, bahwa sesungguhnya pondok pesantren dilahirkan atas kesadaran kewajiban dakwah Islamiyah, yakni menyebarkan dan mengembangkan ajaran Islam, sekaligus mencetak kader-kader ulama dan da 'i/muballigh [32].

Pada masa penjajahan kolonial Belanda, yaitu sekitar abad ke-18-an, nama pondok pesantren sebagai lembaga pendidikan rakyat terasa sangat berbobot terutama dalam bidang penyiaran agama Islam. Kelahiran pondok pesantren baru, selalu diawali dengan cerita perang nilai antara pondok pesantren yang akan berdiri dengan masyarakat sekitarnya, dan diakhiri dengan kemenangan pihak pesantren, sehingga pesantren dapat diterima untuk hidup di masyarakat, dan kemudian menjadi pioner bagi masyarakat sekitarnya dalam bidang kehidupan moral. Kehadiran pondok pesantren di tengah-tengah masyarakat tidak hanya sebagai lembaga pendidikan, tetapi juga sebagai lembaga penyiaran agama dan sosial keagamaan. Dengan sifatnya yang lentur (flexibel), sejak awal kehadirannya, pesantren ternyata mampu mengadaptasikan diri dengan masyarakat serta memenuhi tuntutan masyarakat. Walaupun pada masa penjajahan, pesantren mendapat tekanan dari pemerintah kolonial Belanda, pesantren masih bertahan terus dan tetap tegar berdiri, walaupun sebagian besar berada di daerah 
perdesaan. Peranan mendidik dan mencerdaskan kehidupan bangsa tetap diemban oleh pesantren. Bahkan pada saat-saat perjuangan kemerdekaan banyak tokoh pejuang dan pahlawan-pahlawan kemerdekaan yang berasal dari kaum santri [33].

Keberadaan pesantren, turut menghiasi sejarah pendidikan nasional dan bahkan sejarah perjuangan bangsa melawan colonial, sehingga pondok pesantren yang tersebar di seluruh pelosok negeri dengan santrinya yang puluhan ribuan jumlahnya, menjadi aset nasional yang memerluakan pemikiran dan strategi pengembangan serta penguatan perannya yang lebih maju dan tanpa mengabaikan citranya. Oleh karena itu, untuk saat sekarang, pesantren dalam subsistem pendidikan nasional di Indonesia merupakan bagian integral dari lembaga keagamaan yang secara unik memiliki potensi yang berbeda dengan lembaga pendidikan lainnya. Hal tersebut dapat disimak dari uraian sebelumnya tentang kedudukan pesantren yang menegaskan bahwa dari segi pengelolaannya pesantren bersentuhan langsung dengan pendekatan keagamaan [34].

\section{B. Peran Pesantren dalam Pemberdayaan dan Pembangunan Pertahanan Umat Islam di Era Society 5.0}

Kedudukan pesantren dalam sistem pendidikan nasional memiliki peran yang urgen dan signifikan sehingga perlu pengembangan dan penguatan peran pesantren, sehingga ada dua hal penting yang perlu diperhatikan, yaitu pengembangan dari segi eksternal dan dari segi internal. Dari segi eksternal, citra pesantren harus tetap terjaga di mata masyarakat, yaitu mutu keluaran atau output pesantren harus mempunyai nilai tambah dari keluaran pendidikan lainnya yang sederajat. Santri-santri dalam pesantren hendaknya dipersiapkan untuk mampu berkompetisi dalam masyarakat yang majemuk. Pesantren hendaknya terbuka terhadap setiap perkembangan dan temuan-temuan ilmiah dalam masyarakat, termasuk temuan baru dalam dunia pendidikan. Sedangkan dari segi internal yang perlu dilakukan yaitu bahwa kurikulum pesantren dapat mengeliminasi anggapan yang bersifat dikotomis, yang memisahkan pengetahuan agama dengan pengetahuan umum. Dalam kondisi sekarang kurikulum berdiferensiasi yaitu kurikulum yang direncanakan sedemikian rupa untuk memenuhi kebutuhan anak didik. Kurikulum ini sekaligus dapat menyatukan dengan baik antara aspek intelektual emosional, agama spritual, dan kinerja psikomotor.

Di era industri 4.0 dan society 5.0 sekarang ini pesantren memiliki fungsi pemberdayaan umat, terutama umat Islam. Salah satu penelitian yang dilakukan oleh Lazuardian \& Zaki [35] menghasilkan simpulan bahwa 1) Pesantren Riyadhul Jannah Desa Pacet Mojokerto memiliki peran dalam pemberdayaan masyarakat sekitarnya. Peran pesantren ditunjukkan dengan aktivitas unit-unit usaha milik pesantren yang dinaungi PT. Rijan Dinamis Selaras yang melibatkan masyarakat. Dari aktivitas pemberdayaan masyarakat yang dijalankan pesantren, berbagai manfaat dapat dirasakan langsung oleh masyarakat Desa Pacet dan sekitarnya. Pertama, dapat membuka lapangan kerja baru bagi masyarakat. Hal ini ditandai dengan aktivitas unit-unit usaha di bawah naungan PT. Rijan Dinamis Selaras. Kedua, dapat terjalin kerja sama antara pihak pesantren dan masyarakat sekitar melalui akad muzara'ah di unit usaha bidang pertanian dan penanaman modal atau investasi di Rumah Makan Dapur M'riah. Ketiga, terciptanya wirausaha baru melalui pembinaan dari pihak pesantren. Terciptanya usaha kecil dari masyarakat, diharapkan mampu membuka lapangan kerja sehingga dapat menyerap tenaga kerja baru. Keempat, terciptanya pemerataan pendapatan kepada masyarakat yang diberdayakan oleh pihak pesantren. Pemerataan pendapatan ditandai dengan pembagian upah untuk pegawai yang ada di unit-unit usaha pesantren, serta bagi hasil untuk investor atas kerja sama dalam memajukan Rumah makan Dapur M'riah. Bentuk pemerataan pendapatan ditandai dengan meningkatnya kemakmuran masyarakat sekitar pesantren. Penelitian Falah \& Zaki [36] juga 
mengaskan bahwa pesantren memiliki peran dalam pemberdayaan ekonomi masyarakat di sekitarnya.

Penelitian yang dilakukan oleh Nurhadi, Subiyantoro, dan Hadi [37] juga menunjukkan bahwa pesantren berperan penting dalam pemberdayaan masyarakat, terutama para santrinya. Hasil penelitian menunjukkan bahwa pesantren berperan dalam pemberdayaan santri dalam bidang keagamaan, bidang pendidikan, dan bidang sosial budaya. Dengan pemberdayaan dalam tiga bidang inilah pesantren dapat membangun ketahanan dalam menghadapi era milenial yang desruptif. Hasil penelitian Fathoni dan Rohim [38] memperkuat peran pesantren dalam membangun ketahanan umat Islam, khususnya dalam hal ekonomi. Penelitian ini membuktikan bahwa pesantren memiliki sumber daya yang potensial sehingga layak dijadikan pelopor pemberdayaan ekonomi umat. Cara yang bisa dilakukan pesantren dalam memberdayakan ekonomi umat terbagi dalam beberapa aspek, yaitu aspek lapangan pekerjaan, peluang usaha serta pendirian badan usaha, lembaga keuangan dan/atau lembaga sosial pesantren, dan aspek edukasi santri. Pemberdayaan ekonomi umat berbasis pesantren ini sangat tepat dilakukan sambil berdakwah.

Masih banyak hasil-hasil penelitian yang menjadi bukti bahwa pesantren benar-benar berperan dalam memberdayakan masyarakat di samping empat penelitian di atas. Di antara penelitian tersebut yaitu penelitian Sugandi, Tanjung, \& Rusli [39] tentang peran pondok pesantren modern dalam pemberdayaan ekonomi masyarakat dan penelitian Subekti dan Fauzi [40] tentang peran pondok pesantren dalam pemberdayaan masyarakat sekitar. Semua hasil penelitian ini menjadi bukti bahwa pesantren memang benar-benar menjadi salah lembaga pendidikan Islam yang memiliki peran penting di era industri 4.0 dan era society 5.0 dengan berbagai perubahan yang menyertainya. Pesantren mampu memperkuat ketahanan dan pertahanan kepribadian dan moral santri dan seluruh masyarakat di lingkungan pesantren sehingga tetap memiliki keyakinan dan ketangguhan dalam hidup dan kehidupannya. Zuhri [41] menegaskan bahwa pesantren memang hadir untuk merespons situasi dan kondisi sosial yang dihadapkan pada rusaknya sendi-sendi moral melalui transformasi nilai yang ditawarkannya. Kehadiran pesantren dapat dikatakan sebagai agen perubahan sosial yang selalu melakukan pembebasan bagi masyarakat dari keterpurukan moral, penindasan, kemiskinan, dan berbagai problem sosial lainnya.

\section{KESIMPULAN}

Dari uraian hasil dan pembahasan di atas dapat ditarik simpulan bahwa pesantren memiliki peran yang sangat penting di era industri 4.0 dan era society 5.0. Perkembangan IPTEKS dengan berbagai konsekuensinya di era teknologi, komunikasi, dan transportasi sekarang ini terkadang bisa berdampak negatif bagi bagi pendidikan dan tujuannya yakni pembangunan moral manusia.

Pendidikan Islam menjadi urgen untuk dapat membekali manusia-manusia di era sekarang ini agar tetap dapat mempertahankan jati dirnya sebagai manusia Indonesia yang menjunjung tinggi nilai-nilai religius dan nilai-nilai kemanusiaan. Pendidikan Islam harus responsif dalam menyikapi dinamika perubahan yang terjadi di era desruptif ini.

Sebagai salah satu institusi Pendidikan Islam di Indonesia, bahkan yang pertama dan tertua, pesantren memainkan peran yang sangat penting dan urgen. Upaya pemberdayaan yang dilakukan pesantren terhadap para santri dan masyarakat di sekitar pesantren diharapkan dapat membangun ketahanan dan pertahanan manusia dalam menghadapi dampak negatif dari era indsutri 4.0 dan menyongsong era society 5.0. 


\section{UCAPAN TERIMA KASIH}

Ucapan terima kasih disampaikan kepada Ketua Seminar Nasional Sains, Teknologi, dan Inovasi Indonesia (SENASTINDO) tahun 2021 di Akademi Angkatan Udara Yogyakarta atas terbitnya naskah ini sebagai bagian kolaborasi dan kerja sama penelitian antara Universitas Negeri Yogyakarta dan Akademi Angkatan Udara Yogyakarta.

\section{REFERENSI}

[1] Y. M. Yani dan I. Montratama, "Indonesia sebagai Poros Maritim Dunia: Suatu Tinjauan Geopolitik," dalam Jurnal Pertahanan \& Bela Negara, vol. 5, no. 2, pp. 25-52, 2018, doi: http://dx.doi. org/10.33172/jpbh.v5i2.356.

[2] A. A. Rahma, "Potensi Sumber Daya Alam dalam Mengembangkan Sektor Pariwisata di Indonesia," dalam Jurnal Nasional Pariwisata, vol. 12, no. 1, pp. 1-8, 2020, doi: https://doi. org/10.22146/jnp.52178.

[3] V. B. Kusnandar, "India Negara Berpenduduk Muslim Terbesar Dunia Mulai 2030, Indonesia kedua" (2021) [Online]. Available: https://databoks.katadata.co.id/datapublish/2021/10/11/india-negaraberpenduduk-muslim-terbesar-dunia-mulai-2030-indonesia-kedua.

[4] I. Indriya, I. Indrayanto, dan S. Falah, "Telaah pendidikan Islam di Rusia dan Indonesia (Pengaruh Sejarah Pendidikan Islam di Rusia dan Indonesia terhadap Perkembangan Islam)," dalam Edukasi Islami: Jurnal Pendidikan Islam, vol. 10, no. 1, pp. 263-286, 2021, doi: http://dx.doi.org/10.30868/ei.v10i01.955.

[5] M. Qomar, Pesantren: Dari Transformasi Metodologi Menuju Demokratisasi Institusi. Surabaya: Erlangga, 2002.

[6] E. Srimulyani, Women from Traditional Islamic Educational Institutions in Indonesia: Negotiating Public Spaces. Amsterdam: Amsterdam University Press, 2012.

[7] A. Maksum, "Model Pendidikan Toleransi di Pesantren Modern dan Salaf," dalam Jurnal Pendidikan Agama Islam (Journal of Islamic Education Studies), vol. 3, no. 1, pp. 81-108, 2015, doi: https://doi.org/10.15642/jpai.2015.3.1.81-108.

[8] Marzuki, Miftahuddin, dan M. Murdiono, "Multicultural Education in Salaf Pesantren and Prevention of Religious Radicalism in Indonesia," in Cakrawala Pendidikan, vol. 39, no. 1, pp. 12-25, 2020, doi: https://doi.org/10.21831/cp.v39i1.22900.

[9] A. Darmadji, "Pondok Pesantren dan Deradikalisasi Islam di Indonesia," dalam Millah: Jurnal Studi Agama, vol. 11, no. 1, pp. 235-252, 2011, doi: https://doi.org/10.20885/millah. vol11.iss1.art12.

[10] I. Masduqi, "Deradikalisasi Pendidikan Islam Berbasis Khazanah Pesantren," dalam Jurnal Pendidikan Islam, vol. 2, no. 1, pp. 1-20, 2013, doi: 10.14421/jpi.2013.21.1-20.

[11] T. Y. Kusmanto, M. Fauzi, dan M. M. Jamil, "Dialektika Radikalisme dan Anti Radikalisme di Pesantren," dalam Walisongo: Jurnal Penelitian Sosial Keagamaan, vol. 23, no. 1, pp. 27-50, 2015, doi: http://dx.doi.org/10.21580/ws.23.1.221.

[12] Jakaria, A. Mundzir, S. V. Riorini, dkk., Peningkatan Ekonomi Masyarakat Menuju Era Society 5.0 di Tengah Pandemi Covid-19. Cirebon: Penerbit Insania, 2021.

[13] H. Prasetyo dan W. Sutopo, "Industri 4.0: Telaah Klasifikasi Aspek dan Arah Perkembangan Riset," dalam $J @ t i$ Undip: Jurnal Teknik Industri, vol. 13, no. 1, pp. 17-26, 2018, doi: https://doi.org/10.14710/jati.13.1.17-26.

[14] I. Sabri, "Peran Pendidikan Seni di Era Society 5.0 untuk Revolusi Industri 4.0," dalam Seminar Nasional $\begin{array}{lllllll}\text { Pascasarjana 2019, } & \text { vol. } 2, \quad \text { no. } & \text { 2, } & \text { 342-347, }\end{array}$ https://proceeding.unnes.ac.id/index.php/snpasca/article/view/302.

[15] Jakaria, A. Mundzir, S. V. Riorini, dkk., Peningkatan Ekonomi Masyarakat Menuju Era Society 5.0 di Tengah Pandemi Covid-19. Cirebon: Penerbit Insania, 2021.

[16] A. Tafsir, dkk., Cakrawala Pemikiran Pendidikan Islam. Bandung: Mimbar Pustaka, 2004.

[17] M. A. al-Abrasyi, Dasar-dasar Pokok Pendidikan Islam (Terj. Oleh H. Bustami A. Gani dan Djohar Bahry L.I.S.). Jakarta: Bulan Bintang, 1987.

[18] Marzuki, Pembinaan Karakter Mahasiswa Melalui Pendidikan Agama Islam di Perguruan Tinggi Umum. Yogyakarta: Penerbit Ombak, 2012.

[19] H. Herman, "Sejarah Pesantren di Indonesia," dalam Al-TA'DIB: Jurnal Kajian Ilmu Kependidikan, vol. 6, no. 2, pp. 145-158, 2013.

[20] M. I. Usman, "Pesantren Sebagai Lembaga Pendidikan Islam (Sejarah Lahir, Sistem Pendidikan, dan Perkembangannya Masa Kini)," dalam Jurnal Al-Hikmah, vol. 14, no. 1, pp. 101-119, 2013.

[21] Z. Dhofier, Tradisi Pesantren: Studi Tentang Pandangan Hidup Kyai. Jakarta: LP3ES, 1994.

[22] Mastuhu, Dinamika Sistem Pendidikan Pesantren. Jakarta: PT. Raja Grafindo Persada, 1994.

[23] B. M. Alwi, "Pondok Pesantren: Ciri Khas, Perkembangan, dan Sistem Pendidikannya," dalam Lentera Pendidikan: Jurnal Ilmu Tarbiyah dan Keguruan, vol. 6, no. 2, pp. 205-219, 2016, doi: https://doi.org/10.24252/lp.2013v16n2a8.

[24] Hasyim dan A. Botma, Konsep Pengembangan Pendidikan Islam: Telaah Kritits Terhadap Lembaga Pendidikan Madrasah dan Pondok Pesantren. Makassar: Penerbit Kedai Aksara, 2014. 
[25] S. Wagiman, The Modernization of The Pesantren's Educational System to Meet the Needs of Indonesian Communities (Issue July). McGill, Canada: McGill University, 2017.

[26] Z. Dhofier, Tradisi Pesantren: Studi Tentang Pandangan Hidup Kyai. Jakarta: LP3ES, 1994.

[27] K. Krippendorff and M. A. Bock, The Content Analysis Reader. Pennsylvania, USA: SAGE Publications, Inc., 2008.

[28] Hasyim dan A. Botma, Konsep Pengembangan Pendidikan Islam: Telaah Kritits Terhadap Lembaga Pendidikan Madrasah dan Pondok Pesantren. Makassar: Penerbit Kedai Aksara, 2014.

[29] Hasyim dan A. Botma, Konsep Pengembangan Pendidikan Islam: Telaah Kritits Terhadap Lembaga Pendidikan Madrasah dan Pondok Pesantren. Makassar: Penerbit Kedai Aksara, 2014.

[30] Z. Dhofier, Tradisi Pesantren: Studi Tentang Pandangan Hidup Kyai. Jakarta: LP3ES, 1994.

[31] Hasyim dan A. Botma, Konsep Pengembangan Pendidikan Islam: Telaah Kritits Terhadap Lembaga Pendidikan Madrasah dan Pondok Pesantren. Makassar: Penerbit Kedai Aksara, 2014.

[32] Hasyim dan A. Botma, Konsep Pengembangan Pendidikan Islam: Telaah Kritits Terhadap Lembaga Pendidikan Madrasah dan Pondok Pesantren. Makassar: Penerbit Kedai Aksara, 2014.

[33] Hasyim dan A. Botma, Konsep Pengembangan Pendidikan Islam: Telaah Kritits Terhadap Lembaga Pendidikan Madrasah dan Pondok Pesantren. Makassar: Penerbit Kedai Aksara, 2014.

[34] Hasyim dan A. Botma, Konsep Pengembangan Pendidikan Islam: Telaah Kritits Terhadap Lembaga Pendidikan Madrasah dan Pondok Pesantren. Makassar: Penerbit Kedai Aksara, 2014.

[35] R. Lazuardian dan I. Zaki, "Kontribusi Pondok Pesantren Riyadhul Jannah dalam Memberdayakan Ekonomi Masyarakat Desa Pacet Mojokerto,", dalam Jurnal Ekonomi Syariah Teori dan Terapan, vol. 7, no. 3, pp. 472485, 2020, doi: 10.20473/vol7iss20203pp472-485.

[36] S. Falah dan I. Zaki, "Pemberdayaan Ekonomi Masyarakat Ala Pondok Pesantren di Kelurahan Kejawan Putih Tambak Surabaya," dalam Jurnal Ekonomi Syariah Teori dan Terapan, vol. 4, no. 4, pp. 340-352, 2017, doi: http://dx.doi.org/10.20473/vol4iss20174pp340-352.

[37] I. Nurhadi, H. Subiyantoro, dan N. U. Hadi, "Pemberdayaan Masyarakat Pondok Pesantren untuk Meningkatkan Minat Masyarakat: Studi Kasus Pemberdayaan Santri Pondok Pesantren Nurul Ulum Munjungan," dalam AlIdarah: Jurnal Kependidikan Islam, vol. 8, no. 1, pp. 142-153, 2018, doi: https://doi.org/10.24042/alidarah.v8i1.3085.

[38] M. A. Fathoni dan A. N. Rohim, "Peran Pesantren dalam Pemberdayaan Ekonomi Umat di Indonesia, in Proceeding of Conference on Islamic Management, Accounting, and Economics, Agustus 2019, vol. 2, pp. 133-140.

[39] A. Sugandi, H. B. Tanjung, dan R. K. Rusli, "Peran Pondok Pesantren (Ponpes) Modern dalam Pemberdayaan Ekonomi Masyarakat," dalam Tadbir Muwahhid, vol. 1, no. 2, pp. 99-115, 2017, doi: https://doi.org/10.30997/jtm.v1i2.950.

[40] M. Y. A. Subekti dan M. M. Fauzi, "Peran Pondok Pesantren dalam Pemberdayaan Masyarakat Sekitar," dalam Al-I'tibar: Jurnal Pendidikan Islam, vol. 5, no. 2, pp. 99-100, 2018, doi: https://doi.org/10.30599/jpia.v5i2.554.

[41] S. Zuhri, "Pendidikan Pesantren di Persimpangan Jalan," dalam Marzuki Wahid, dkk. (ed), Pesantren Masa Depan Wacana Pemberdayaan dan Transformasi Pesantren. Bandung: Pustaka Hidayah, 1999. 